\title{
UNIVERSITYOF BIRMINGHAM

\section{Of Custom, Treaties, Scholars and the Gavel: The Influence of the International Criminal Tribunals on the ICRC Customary Law Study}

Cryer, Robert

DOI:

$10.1093 / \mathrm{jcsl} / \mathrm{krl} 008$

Citation for published version (Harvard):

Cryer, R 2006, 'Of Custom, Treaties, Scholars and the Gavel: The Influence of the International Criminal

Tribunals on the ICRC Customary Law Study', Journal of Conflict and Security Law, vol. 11, no. 2, pp. $239-263$. https://doi.org/10.1093/jcsl/krl008

Link to publication on Research at Birmingham portal

\section{General rights}

Unless a licence is specified above, all rights (including copyright and moral rights) in this document are retained by the authors and/or the copyright holders. The express permission of the copyright holder must be obtained for any use of this material other than for purposes permitted by law.

- Users may freely distribute the URL that is used to identify this publication.

- Users may download and/or print one copy of the publication from the University of Birmingham research portal for the purpose of private study or non-commercial research.

- User may use extracts from the document in line with the concept of 'fair dealing' under the Copyright, Designs and Patents Act 1988 (?)

- Users may not further distribute the material nor use it for the purposes of commercial gain.

Where a licence is displayed above, please note the terms and conditions of the licence govern your use of this document.

When citing, please reference the published version.

Take down policy

While the University of Birmingham exercises care and attention in making items available there are rare occasions when an item has been uploaded in error or has been deemed to be commercially or otherwise sensitive.

If you believe that this is the case for this document, please contact UBIRA@lists.bham.ac.uk providing details and we will remove access to the work immediately and investigate. 


\title{
Of Custom, Treaties, Scholars and the Gavel: The Influence of THE INTERNATIONAL CRIMINAL TRIBUNALS ON THE ICRC CUSTOMARY LAW STUDY
}

\author{
Robert Cryer
}

\section{INTRODUCTION}

The revival of humanitarian law as a subject of study has been at least in part an outcropping of the work of the international criminal tribunals created in the 1990s. Therefore it is no surprise that the influence of those tribunals on international law has been commented upon considerably. ${ }^{1}$ However, outside of scholarly speculations it has not been that easy to obtain clear evidence of how much influence those tribunals have had on customary law aside from their own decisions. ${ }^{2}$ There are two ways in which the tribunals may have affected views of customary law, through their constituent treaties and their jurisprudence. Neither is free from complexity or controversy. The difficulty involved in attempting to perceive the manner in which judicial decisions influence, or become considered reflective of, custom has been commented upon by Sir Hersch Lauterpacht, who brought his usual sagacity to the subject, stating that ' $[t$ he imperceptible process by which the judicial decision ceases to be an application of existing law and becomes a source of law for the future is almost a religious mystery into which it is unseemly to pry. ${ }^{33}$ The relationship between treaties and custom has also been the subject of much discussion, upon which there is no shortage of dispute both at the general level and on particular rules.

\footnotetext{
* School of Law, University of Nottingham. I am very grateful to all the participants in the roundtable for their contributions to the roundtable and the considerable assistance I have drawn from the papers presented and the discussion they engendered, which has considerably improved my understanding of the study. I would like, in addition, to thank Dieter Fleck, Sangeeta Shah and Nigel White for their comments on an earlier draft.

${ }^{1}$ See, e.g. Theodor Meron, 'War Crimes in Yugoslavia and the Development of International Law' (1994) 88 American Journal of International Law 78; Christopher Greenwood, 'The Development of International Humanitarian Law by the International Criminal Tribunal for the Former Yugoslavia' (1998) 2 Max Planck Yearbook of United Nations Law 97; William Fenrick, 'The Development of the Law of Armed Conflict Through the Jurisprudence of the International Criminal Tribunal for the Former Yugoslavia' (1998) 3 Journal of Armed Conflict Law 197.

2 Which, of course, might be expected to take a sanguine view of their earlier pronouncements. On the other hand, certain influences, such as that of the Tadic interlocutory appeal (Prosecutor $\mathrm{v}$ Tadic Decision on Interlocutory Appeal on Jurisdiction, IT-94-1-AR72, 2 October 1995) on the ICC Statute can be seen, see, e.g. Lindsay Moir, The Law of Internal Armed Conflict (Cambridge: CUP, 2002) p.160.

${ }^{3}$ Sir Hersch Lauterpacht, The Development of International Law by the International Court (London: Stevens, 1958) p.21.
} 
Against this background, the ICRC customary law study, ${ }^{4}$ which not only sets out the rules it thinks are customary, but seeks to show its 'working out' gives us an exceptional chance to evaluate how the international criminal tribunals and their practice have been seen by an independent international actor. ${ }^{5}$ Indeed, an actor which has been mandated by the Geneva Conventions to act as a guardian of humanitarian law. ${ }^{6}$ This opportunity is made even more enticing because the Study makes very heavy use of the work of the ICTY and the ICC Statute. A quick count of the reliance of the Study on the ICTY and ICC reveals that their statutes or case-law are referred to over 170 times prior to the sections dealing with implementation and enforcement of humanitarian law. Unsurprisingly, in those sections reliance on those tribunals' foundational documents and practice is even more pronounced. ${ }^{7}$ It might be noted, however, that reliance on the ICTR Statute is less notable, and the Tokyo IMT almost non-existent. ${ }^{8}$ This replicates the secondary status to which those Tribunals have, unfortunately, been relegated.

The Study had been described as a photograph, ${ }^{9}$ but it can be seen in a different manner, namely as a great impressionist painting. From a broad view, in its general conception and in many ways, it is a masterpiece, but the closer the look taken into the way it approaches custom is, the less beautiful it can seem. However, it has to be said that although by looking too closely at individual aspects of the Study, its overall quality can be missed. But the point is that a close analysis is important if the study is to be the beginning of discussions about IHL, ${ }^{10}$ which given its caliber, and thorough research base, it deserves to be.

Given that the study has already had an impact on courts both international and national, ${ }^{11}$ and been the subject of heavy, if not unpredictable, criticism from republicans in the US, ${ }^{12}$ it

\footnotetext{
${ }^{4}$ Jean-Marie Henckaerts and Louise Doswald-Beck, Customary International Humanitarian Law (Cambridge: CUP, 2005), [hereinafter Study].

5 The precise status of the study as an ICRC document is a little more complex than might be thought. Although it was mandated by the $26^{\text {th }}$ Conference of the Red Cross and Crescent, contains the ICRC logo on the cover and is said by the ICRC President to be believed by the ICRC to be an accurate statement of the law (Jakob Kellenberger, 'Foreword' in the Study ix, p.xi) it is not a formal ICRC statement of views, and the ICRC states that it 'respected the academic freedom both of the report's authors and the experts consulted' (ibid.). The Study (even if in preparation) is conspicuously absent from François Bugnion, 'The International Committee of the Red Cross and the Development of International Humanitarian Law' (2004-2005) 5 Chicago Journal of International Law 191.

${ }^{6}$ See, e.g. 1949 Geneva Convention III Relative to Prisoners of War, 75 UNTS 135, Articles 3, 123, $125,126$. Protocol Additional to the Geneva Conventions of 12 August 1949, 1125 UNTS 3, Article 5(3).

${ }^{7}$ On the ICTR and international law see Larissa J. van den Herik, The International Criminal Tribunal for Rwanda and the Development of International Law (The Hague: Brill, 2005).

${ }^{8}$ The only notable use is in relation to command responsibility, see e.g. Study, Vol II, pp. 3768-3772

9 Jakob Kellenberger, 'Foreword' in the Study ix, p.xi,.Yves Sandoz, 'Foreword' in the Study, xiv, p.xvii.

${ }^{10}$ Sandoz, 'Foreword', in the Study, p.xvii.

11 See Prosecutor v Hažihasanovic and Kubura, Decision on Joint Defence Interlocutory Appeal of Trial Chamber Decision on Rule 98bis Motions for Acquittal, IT-01-47-AR73.3, 11 March 2005, paras 29-30,38,45-46 and domestically, Adalah and others v GOC Central Command, IDF and others, Israel Supreme Court, 23 June 2005 , HCJ, 3799, 02, paras 20, 21, 24. Theodor Meron avers that the Study 'will be a significant aid to international criminal tribunals', Theodor Meron, 'Revival of Customary Humanitarian Law' (2005) 99 American Journal of International Law 817, p.833.
} 
is important, even for those sympathetic to the study, ${ }^{13}$ to appraise the study as objectively as possible, even though the aims of the study are unquestionably meritorious. In order to do this, it is necessary to begin by setting the international legal scene, of the general approach to treaties, judicial decisions and customary law in international law. Owing to some of the comments which will be offered later, it is also necessary to engage in a short excursus on the role of academics in international law.

\section{Treaties AND Custom}

With the possible exception of the Tokyo IMT, the statutes of international criminal tribunals all find their basis in treaty law. ${ }^{14}$ The London Charter of the Nuremberg IMT was a treaty. ${ }^{15}$ The Statutes of the ICTY and ICTR, although promulgated by the Security Council, find their legal basis in Chapter VII and Article 25 of the UN Charter. ${ }^{16}$ Although the Statutes are not, in themselves, treaties, they are sufficiently analogous to them (and have been treated as such by the Tribunals) ${ }^{17}$ that for the purposes of this article they may be considered under that rubric. The Rome Statute is a multilateral treaty, and the legal basis of the Special Court for Sierra Leone is a treaty between the UN and Sierra Leone. ${ }^{18}$ Therefore it is apposite to digress for a moment into the relationship between treaties and custom. ${ }^{19}$

12 On which see Iain Scobbie, 'The Approach of the Study to Customary Law??' (2006) 11 Journal of Conflict and Security Law ??, pp.??; see also Malcolm Maclaren and Felix Schwendimann, 'An Exercise in the Development of International Law: The New ICRC Study on Customary International Law' (2005) 6 German Law Journal, 1217, pp.1237-1238. There has also been criticism from members of the US forces, see, e.g. W. Hays Parks, 'The ICRC Customary Study: A Preliminary Assessment' (2005) 999 Proceedings of the American Society of International Law 208.

13 Of which I consider myself to be one. Lest there be any misinterpretation of this piece, the compliments herein directed to the Study are not sops to professional courtesy, but a reflection of genuine admiration for the study, and the criticisms ought to be read against the background of my support for most of what the Study says, and its intentions in full.

${ }^{14}$ Even in the case of the Tokyo IMT, its basis is probably treaty law, i.e. the instrument of surrender between Japan and the Allies.

151945 Agreement for the Prosecution and Punishment of the Major War Criminals of the European Axis Powers and Charter of the International Military Tribunal, 82 UNTS 279.

${ }_{16}$ Prosecutor v Tadic, supra n.2, paras 28-40.

17 See, e.g. William A. Schabas, 'Interpreting the Statutes of the ad hoc Tribunals' in Lal Chand Vohrah et al (eds.), Man's Inbumanity to Man: Essays on International Law in Honour of Antonio Cassese (The Hague: Kluwer, 2003) 847, pp.849-870.

182001 Agreement Between the United Nations and Sierra Leone on the Establishment of a Special Court. This article treats the Special Court as an international tribunal solely on the basis that the Study does. In spite of its protestations to the contrary, (see, e.g. Prosecutor v Taylor, Decision on Immunity, SCSL-2003-01-I, 31 May 2004, paras 37-42) the Special Court is a hybrid tribunal. For criticism of the Special Court's views see Zsuzsanna Deen-Racsmány, 'Prosecutor $v$ Taylor: The Status of the Special Court for Sierra Leone and Its Implications for Immunity’ (2005) 18 Leiden Journal of International Law 299.

19 Probably the classic work in the area is Richard R. Baxter, 'Multilateral Treaties as Evidence of Customary International Law' (1965-1966) 41 British Yearbook of International Law 275. A more modern, and very useful study is Mark Villiger, Treaties and Custom: A Manual on the Theory and Practice of the Interrelationship of Sources (The Hague: Kluwer, $2^{\text {nd }}$ ed., 1997). See also Michael Byers, Custom: Power and the Power of Rules: International Relation and Customary International Law (Cambridge: CUP, 1999) pp.166-180; Jonathan I. Charney, 'International Agreements and the Development of Customary International Law' (1986) 61 Washington Law Review 971. For a critical view of scholarship on the relationship between treaties and custom see Arthur M. Weisburd, 'Customary International Law: The Problem of Treaties' (1988) 21 Vanderbilt Journal of Transnational Law 1. 
Treaties and custom have what has accurately been described as an 'entangled' relationship. ${ }^{20}$ The three ways in which treaties may interplay with customary law are, as is well known, summed up in the North Sea Continental Shelf Case. ${ }^{21}$ They are either that the treaty is drafted to reflect customary law at the time of its adoption, that the negotiating process crystallizes the customary rule, or that a treaty provision subsequently becomes accepted as reflecting custom. $^{22}$ The difficulty, of course, is not stating the general propositions in this manner, but in determining in when each applies, or if any apply at all.

Certain matters are tolerably clear however. One is that, as the ILA committee on the formation of customary law noted, there is no presumption that a treaty is reflective of customary international laws at the time of its conclusion. ${ }^{23}$ There has been some support for the proposition that humanitarian law treaties are an exception to this. ${ }^{24}$ When Richard Baxter, who is often cited as the fons et origio of this idea, canvassed the possibility it was only as a matter of lex ferenda. ${ }^{25}$ Nonetheless, there is some evidence that in relation to humanitarian law the standards of proof in relation to customary law have been relaxed when compared to other areas of law, particularly by tribunals dealing with the matter. ${ }^{26}$

Even so, care must be taken with this argument, as a tendency to adopt the view that humanitarian law is customary without adequate proof is unlikely to convince skeptics of the accuracy of the result. There is no rule of international law that provides for a special status for humanitarian law in relation to the formation of customary law and it is a matter of evidence in any individual case whether or not a treaty rule represents the custom one. ${ }^{27}$

In relation to this, there are a number of factors that have a bearing on proof of the customary status of a treaty rule. The first of these is the extent to which the treaty was considered codificatory at the time of its creation. One piece of evidence that this is the case is the treaty itself stating that it is intended to be codificatory of pre-existing custom. ${ }^{28}$ This is only evidence though; the statement itself may be incorrect (although the more States that ratify the treaty, the more States are estopped from denying the accuracy of the assertion). ${ }^{29}$

\footnotetext{
20 Oscar Schachter, 'Entangled Treaty and Custom' in Yoram Dinstein (ed.), International Law in a Time of Perplexity: Essays in Honour of Shabtai Rosenne (Dordrecht: Martinus Nijhoff, 1989) 717.

21 (1969) ICJ Reports 3.

22 Ibid., paras 60-82. See also International Law Association, Report of the Committee on Formation of Customary (General) International Law 1, pp.42-54.

${ }^{23}$ Ibid., p.43.

${ }^{24}$ Baxter, supra n.19, pp.286, 299.

25 Ibid., This is something misunderstood by Weisburd, supra n.19, pp.39-41.

26 See, e.g. Frederick Kirgis, 'Custom on a Sliding Scale' (1987) 81 American Journal of International Law 146, pp147-150; Theodor Meron, Human Rights and Humanitarian Law as Customary Law (Oxford: OUP 1989). See also Anthea Elizabeth Roberts, 'Traditional and Modern Approaches to Customary International Law: A Reconciliation' (2001) 95 American Journal of International Law 757, pp.764-766, 772-774.

27 See e.g. Michael Akehurst, 'Custom as A Source of international Law' (1976) 47 British Yearbook of International Law 1, pp.45-48. As the Study notes, p.xliii, see Maclaren and Schwendimann, 'Exercise', supra n.12, p.1123.

28 See, e.g. ILA Report, supra n.22, p.44; Villiger, supra n.18, pp.232-236.

${ }^{29}$ Baxter, 'Multilateral Treaties' supra n.19, pp.277-278. Equally, the fact that preambles are not binding has a bearing on the question in situations where the statement of a treaty's codificatory nature is made there, (Villiger, ibid., p.236). And that is where the majority of such statements are made.
} 
Care must be taken where the treaty 'suggest[s] that some (unidentified) conventional rules may be codificatory. These formulations, while in fact providing little enlightenment, at least rule out a presumption that the instrument as a whole constitutes progressive development'. ${ }^{30}$ The next evidence relevant to determining customary status is the travaux préparatoires of the treaty. These may show that the intention of the parties was to codify customary international law in a particular provision, or perhaps even more generally. ${ }^{31}$ This includes ILC Reports where they are relevant. The travaux can also provide evidence that a rule crystallized as customary at a conference.

In relation to a treaty rule which is progressive development of the law at the time of its promulgation, a later finding that it has become customary is perfectly possible. ${ }^{32}$ However, this is not something which is 'lightly to have been regarded as having been attained'. ${ }^{33}$ Nevertheless, this has certainly occurred, and some of the most notable examples have been in humanitarian law. ${ }^{34}$ As with questions of whether a treaty rule is codificatory or if custom crystallised at a drafting conference (or before), questions of evidence are important here.

This should not be a surprise: The question whether a treaty rule has become reflective of customary law is a question of the presence or otherwise of State practice and opinio juris, in the same way as applies to the question of if any purported rule is one of customary law. ${ }^{35}$ In some ways, it can be more difficult to appraise practice in relation to a norm which has a pre-existing treaty basis, as the practice of parties to the treaties inter se can be attributed to the existence of the treaty. ${ }^{36}$ As a result, the practice of State parties to a treaty in relation to third-parties, and their response to that practice is very relevant in determining the customary status of a novel treaty rule. The statements of non-parties as to their views on the customary status of rules can also be very useful here. The existence of a treaty has, in the past, led States to set out their position as to whether or not the rules it contains are an accurate reflection of the custom. In humanitarian law, US views on Additional Protocol I are of particular note. ${ }^{37}$

Turning back to later evidence, one frequently resorted to piece of evidence is the number of States that have ratified the relevant treaty. In some ways this is paradoxical, given that the greater the number of parties, the more practice can be referred to the treaty. ${ }^{38}$ Similarly, the greater the claim of a treaty to customary status at the time of its adoption, the lesser the impetus for States to bother to ratify the convention, as it will not alter their obligations. ${ }^{39}$ Still, a very widely ratified treaty has a considerable 'pull' towards acceptance, as there is a

30 Villiger, Customary Law, ibid., p.232.

31 See Villiger, Customary Law, ibid., pp.231-232.

32 ILA Report, supra n.22, pp.50-54, Villiger, Customary Law, ibid., Chapter 6.

33 North Sea Continental Shelf Case, supra n.21, para 71.

34 ILA Report, supra n.22, p.46. The fact that the major rules of humanitarian law are of a fundamentally normcreating manner is not irrelevant here.

35 Villiger, Customary Law, supra n.19, pp.182-183.

${ }^{36}$ ILA Report, supra n.22, pp.46-47.

37 See, for example, Christopher Greenwood, 'The Customary Status of the 1977 Geneva Protocols' in Astrid J.M. Delissen and Gerard J. Tanja, The Humanitarian Law of Armed Conflict: Challenges Ahead (Dordrecht: Martinus Nijhoff, 1991) 93.

38 See Baxter, 'Multilateral Treaties' supra n.19, pp.282-283.

39 Ibid., pp.285-286. 
feeling that if a treaty is very broadly ratified, it represents the general expectations of those States. ${ }^{40}$ That certainly appears to be the approach taken by international tribunals.

\section{Judicial DeCisions as A SOURCE OF INTERNATIONAL LAW}

As with the relationship between treaties and customary law, the status of judicial decisions as a source of law is a matter upon which the level of literature is particularly high. ${ }^{41}$ Although judicial decisions are only mentioned as a subsidiary means for determining the law in Article 38(1)(d) of the ICJ Statute this understates the practical effect that judicial decisions have on the ascertainment, in particular, of customary international law. It is almost certainly trite now (although it may not have been in 1979) to note, as Igor Blishchenko did, that 'international humanitarian law owes a great deal to decisions handed down by national and international courts. ${ }^{42}$ The concrete form of a judgment, alongside the fact that it is (or at least should be) attended by a reasoned opinion gives a judicial decision considerable weight in international law. ${ }^{43}$ A quick perusal of the commentaries to the ILC Rules on State Responsibility shows that in practice this is the case. ${ }^{44}$ One of the most accurate statements of the status of judicial decisions in international law comes from Oppenheim:

In the absence of anything approaching judicial precedent the common law doctrine of judicial precedent, decisions of international tribunals are not a direct source of law in international adjudications. In fact, however, they exercise considerable influence as an impartial and considered statement of the law by jurists of authority made in light of actual problems which arise before them...it is probable in view of the difficulties surrounding the codification of international law, international tribunals will in the future fulfill, inconspicuously but efficiently, a large part of the task of developing international law ${ }^{45}$

\footnotetext{
${ }^{40}$ Such a process appears to have occurred with respect to at least most of the 1949 Geneva Conventions.

41 The literature is so strong that it is to be hoped that readers will forgive the rather heavy use of quotation in this section. For some of the best examples amongst this literature see, in particular, Lauterpacht, Development, supra n.3; Mohammed Shahabuddeen, Precedent in the World Court (Cambridge: CUP, 1995); Robert Y. Jennings, 'The Judiciary, National and International, and the Development of International Law' (1996) 45 International and Comparative Law Quarterly 1; Georg Schwarzenberger, International Law as Applied By International Courts and Tribunals: Vol 1 (London: Stevens, $3^{\text {rd }}$ ed., 1957).

42 Igor P. Blischenko, 'Judicial Decisions as a Source of International Humanitarian Law' in Antonio Cassese (ed.), The New Humanitarian Law of Armed Conflict (Napoli: Editoriale Scientifica, 1979) 41, p.51. For a modern (and non-trite) appraisal see Guénaël Mettraux, International Crimes and the ad Hoc Tribunals (Oxford: OUP, 2005) pp13-18.

43 Sir Gerald Fitzmaurice, 'Some Problems Regarding the Formal Sources of International Law' (1958) Symbolae Verzijl 153, p.172; Ian Brownlie, The Rule of Law in International Affairs: International Law at the $50^{\text {th }}$ Anniversary of the United Nations (The Hague, Kluwer, 1998) p.28. See also infra ??

44 See James Crawford, The International Law Commission's Articles on State Responsibility: Texts and Commentaries (Cambridge: CUP, 2002).

45 Robert. Y. Jennings and Arthur Watts (eds.), Oppenheim's International Law: Volume I: Peace (London: Longman's, $9^{\text {th }}$ ed., 1992) p.41. The only caveat that may be entered is about the inconspicuous nature of some of some of the development of international law by some courts.
} 
As Mohammed Shahabuddeen has noted, ${ }^{46}$ despite the fact that a court decision cannot create law per se, by recognising the existence of a rule of customary international law a court decision may essentially act as the final stage of the crystallization of that customary rule. ${ }^{47}$ As Sir Robert Jennings has explained though, there are limits to the role that international tribunals may take owing to their nature as law determining, rather than creating, agencies:

D]udges, whether national or international, are not empowered to make new laws. Of course we all know that interpretation does, and indeed should, have a creative element in adapting rules to new situations and needs, and therefore also in developing it even to an extent that might be regarded as changing it. Nevertheless, the principle that judges are not empowered to make new law is a basic principle of the process of adjudication. Any modification and development must be seen to be within the parameters of permissible interpretation. For otherwise judges lose their ultimate source of authority. Litigating parties do not resort to judges because the are wise or statesmenlike-very often they are manifestly neither-but because they know the law. ${ }^{48}$

Similarly, the two bitter interlocutors of the first half of the twentieth century in British academic international law, Sir Hersch Lauterpacht and Georg Schwarzenberger, despite their considerably differing methods, agreed on certain things. One of these was that the decisions of international tribunals were useful evidence of what customary law was, but, and this is a large caveat, this depended on the quality of the decision. Hence Lauterpacht, in The Development of International Law by the International Court said:

the outcome of the general recognition of the persuasive force of judicial precedent has been the development of a comprehensive body of law which, in proportion to its intrinsic method, can be used not only as direct evidence of specific rules of law as understood by the court, but also as indicative of the method and the spirit in which the Court may be counted upon to approach similar cases [emphasis added]. ${ }^{49}$

Schwarzenberger, on the other hand graded court decisions as evidence of international law on the basis of the extent to which the court was impartial, free from personal interest of the judges, had an international outlook and had high technical standards. Even within those courts which, like the ICJ, fulfilled the general criteria, Schwarzenberger believed in looking carefully at the standard of reasoning in cases. ${ }^{50}$ As he said, 'it is probably not accidental that the least convincing statements on international law made by the International Court of Justice excel by a remarkable economy of argument. ${ }^{51}$

\footnotetext{
46 Shahabuddeen, Precedent, supra n.41, p.72.

${ }^{47}$ It might be noted parenthetically that, in the context of State Responsibility, States have expressly used this possibility to argue against any quick attempt to adopt the ILC rules into a treaty see James Crawford and Simon Olleson, 'The Continuing Debate on a UN Convention on State Responsibility' (2005) 54 International and Comparative Law Quarterly 959, pp.960, 966-968.

48 Jennings, 'Judiciary', supra n.41, p.3. Sir Gerald Fitzmaurice, 'Judicial Innovation-Its Uses and Its Perils' in R.Y. Jennings (ed.), Cambridge Essays in International Law in Honour of Lord McNair (London: Stevens, 1965$) 24$.

${ }^{49}$ Lauterpacht, Development, supra n.3, p.18.

50 Schwarzenberger, International Law, supra n.41, p.30.

${ }^{51}$ Ibid., p.32. See also Mettraux, International Crimes, supra n.42, p.15. It might be noted that the ICTY has, on at least one occasion refused to follow an earlier decision of the ICTR it considered badly reasoned, see Prosecutor v Vasiljević, Judgment, .IT-98-32-T, 29 November 2002, footnote 586.
} 
Another word of caution also ought to be mentioned. Where a decision is quoted as evidence of customary law, care must be taken not to 'double-count' the practice in the decision and the decision itself. Cases are useful repositories of practice, and the views taken on them by international judges are entitled to respect. However, the two are, and ought to be separable.

As an aside, it ought to be noted at this point that the proof of evidence of customary international law is not apolitical. A heavy reliance on the jurisprudence of international tribunals can be seen as a deliberate counter-hegemonic strategy. ${ }^{52}$ Ian Brownlie rightly made this clear in his 1995 Hague Academy Course on General International Law '[t]he hegemonial approach will necessarily favour the decisions of the Security Council, especially in the constellation of world politics. It will not tend to favour institutions like the International Court, which cannot be controlled by a small group of States'. ${ }^{53}$ The relevance here of Iain Scobbie's comments hardly needs to be made express. ${ }^{54}$

\section{ACADEMICS AND THE DETERMINATION OF CUSTOMARY INTERNATIONAL LAW}

Although the focus of this piece is not the influence of academics on international law per se, owing to their practical importance in determining the relevant impact of treaties and judicial decisions on customary law it is worth mentioning their role. Academics frequently write on the question of whether a treaty provision is customary or not ${ }^{55}$ and criticise the decisions of courts, particularly in relation to their assertions about customary law. ${ }^{56}$ It is to say the least, unduly self-denying to fail to take account of such work, in particular when engaging in a task such as the Study's, which is to appraise the nature of customary law across such a broad spectrum of rules as humanitarian law encompasses.

\footnotetext{
52 On hegemony and international law generally see Detlev Vagts, 'Hegemonic International Law' (2001) 95 American Journal of International Law 843 and José E. Alvarez, 'Hegemonic International Law Revisited' (2003) 97 American Journal of International Law 873.

53 Brownlie, Rule of Law, supra n.43, p.33.

54 Scobbie, supra n.12, pp.?? Although José Alvarez has expressed doubt at the extent to which the ad hoc tribunals' decisions can be independent of their creators. See José E. Alvarez, 'Crimes of Hate/Crimes of State: Lessons From Rwanda' (1999) 23 Yale Journal of International Law 365, p.398. Alvarez provides no empirical evidence of this at the judicial stage, however, and the extent to which China and Russia welcomed the decisions on the law applicable to non-international armed conflicts and crimes against humanity, inter alia, in Prosecutor v Tadić, supra n.2, paras 96-136 and Prosecutor v Tadić, Judgment, IT-94-1-T, 7 May 1997, para 627 might be queried. Mark Osiel views the ICTY's development of joint criminal enterprise liability as proof of their independence from the US, see, Mark J. Osiel, 'Modes of Participation in Mass Atrocity' (2005) 39 Cornell International Law Journal 793, pp.800-802. Martti Koskenniemi, in stating that the 1999 Tadic appeal (Prosecutor $\mathrm{v}$ Tadic, Judgment, IT-94-1-A, 15 July 1999) demonstrated a 'bias to guarantee as wide a scope for international prosecutions as possible' at least implicitly takes the view that the judges of the ICTY have minds of their own, Martti Koskenniemi, From Apology to Utopia: The Structure of International Legal Argument (Cambridge: CUP, reissue, 2006) pp.586.

55 See, e.g. Antonio Cassese, International Criminal Law (Oxford: OUP, 2003) pp.91-94.

${ }^{56}$ See, e.g. the papers in the 'Agora: The ICJ Advisory Opinion on the Construction of a Wall in the Occupied Palestinian Territory’ (2005) 99 American Journal of International Law 1-141.
} 
Normally, the role of scholars in international law is at best a default one. ${ }^{57}$ Article $38(1)(d)$ of the ICJ Statute treats the outpourings of the most highly qualified publicists as being a subsidiary means of determining the law. There are those who further subordinate the views of scholars to the other subsidiary means of determining the law, judicial decisions. ${ }^{58}$ This is probably accurate, at least in relation to the extent to which a particular statement of law may be taken as authoritative. As Fitzmaurice made clear, the form of a decision and the attitude of parties to international litigation to decisions of tribunals make them of greater weight than the writings of jurists. Equally, judicial decisions often cite or rely on (sub silentio or otherwise) the views of academics. As it happens, this has particularly been the case in relation to humanitarian law through the international criminal tribunals. ${ }^{59}$

Scholars have frequently engaged in detailed studies of customary law, and in doing so, provided evidence of how evidence of custom may be appraised, alongside critiquing claims of customary status by others. ${ }^{60}$ Like case-law, in proportion to their technical standards, such studies are of use in assisting in the determination of custom, and indeed the Study itself, and its judicial reception, is evidence of this utility. ${ }^{61}$

The vast majority of the literature in relation to the impact of scholars on international law deals with the possibility that it has a constructive function, i.e. that scholars will attempt to push the law forward to a position which they consider appropriate. ${ }^{62}$ The constructive effect of scholarship can only be half of the story. As the extent to which a judicial decision's view on what amounts to custom may be considered acceptable relies (inter alia) upon the quality of the reasoning of that decision, critiques of that reasoning are particularly important. Academic demolitions of the reasoning and results in cases can have a

\footnotetext{
57 The classic statement of the role of academics in international law is Clive Parry, The Sources and Evidences of International Law (Manchester: Manchester UP, 1968) pp.103-108.

58 See, for example, Fitzmaurice, 'Some Problems' supra n.43, pp.174-175.

59 See, e.g. Prosecutor v Krstić, Judgment, IT-98-33-A, 19 April 2004, paras 10, 25; Prosecutor v Stakić, Judgment, IT-97-24-T, 31 July 2003 para 519. The famous Tadic interlocutory appeal was clearly influenced by Theodor Meron's work. See, for example, Theodor Meron, 'International Criminalization of Internal Atrocities' (1995) 89 American Journal of International Law 554. Meron was a consultant to the prosecutor in the Tadic litigation.

${ }^{60}$ Perhaps most notable in this regard is Theodor Meron, Human Rights, supra n.25.

${ }^{61}$ Not least, by collecting instances practice together, which States, Courts and advocates may not have the ability or time to do. Scholarly studies have, since at least Vattel's, Principles of the Law of Nations (New York, Carnegie Endowment for International Peace, 1916 (originally 1758)) proved highly influential, and not just amongst scholars, see (from very different perspectives) see B.S. Chimni, International Law and World Order: A Critique of Contemporary Approaches (Delhi: Sage, 1993) pp.229-230; Jeremy Rabkin, Law Without Nations: Why Constitutional Government Requires Sovereign States (Princeton, Princeton UP, 2005) pp.78-81; Koskenniemi, supra n.54, p.112.

${ }^{62}$ See e.g. Sir Robert Jennings, 'International Lawyers and the Progressive Development of International Law' in Jerzy Makarczyk, Theory of International Law at the Threshold of the 21 ${ }^{\text {st }}$ Century: Essays In Honour of Krysztof Skubizewski (The Hague: Kluwer, 1996) 413.
} 
considerable effect on the reception of such decisions. The critical savaging that has attended some of the findings in the Yerodia case is a case in point. ${ }^{63}$

\section{The Approach of THE Study To THE Tribunals}

Bearing in mind the above, it is time (finally) to move on to the approach the study proclaims itself to take to the international tribunals, through their treaties and jurisprudence. The first port of call on this is the introduction to the Study which, quite rightly, seeks to explain its methodology. In relation to the impact of treaties on custom, the study gives a fairly brief explanation of the interrelationship of treaties and custom, with a rather heavy emphasis on the number of parties to treaties ${ }^{64}$ (assumedly owing to the controversial nature of parts of Additional Protocol I). ${ }^{65}$ Even though, as we will see, the study relies quite heavily at times on the Statutes of the ICTY and ICC in particular, the only time the study expressly deals with the normative impact of the Statutes of international criminal tribunals is in relation to the Rome Statute. Thus we are not told of the relevant normative value of the other Tribunals' Statutes at all. Given the extent to which they are relied upon, this is unfortunate, and indicative of one of the problems with the study- it is often silent on the weight given to particular evidences of custom, a point to which we will return.

As it happens, the ICTY Statute, owing to the intention of its drafters, is very good evidence of customary law. This is because the Secretary-General's Report on the ICTY, which is analogous to the travaux préparatiores of a treaty, makes clear that the intention in drafting the Statute was to stay within the bounds of customary law: 'the application of the principle nullum crimen sine lege requires that the international tribunal should apply rules of international humanitarian law which are beyond any doubt part of customary law so that the problem of adherence to some but not all States to specific conventions does not arise'. ${ }^{66}$

The same is not necessarily the case in relation to the Rwanda Tribunal. The SecretaryGeneral was not involved in the drafting of the ICTR's statute, ${ }^{67}$ and there are no analogues to travaux for it. The Secretary-General did report on the Statute, however, and gave some remarks which are relevant to the appraisal of its customary status. Commenting on the war

\footnotetext{
63 Case Concerning the Arrest Warrant of 11 April 2000 (Democratic Republic of Congo $v$ Belgium) ICJ General List 121, 14 February 2002. For a selection of the critical literature see Antonio Cassese, 'When May Senior State Officials Be Prosecuted for International Crimes: Some comments on the Congo v Belgium Case’ (2002) 13 European Journal of International Law 853; Steffen Wirth, 'Immunity for Core Crimes? The ICJ's Judgment in the Congo v Belgium Case' (2002) 13 European Journal of International Law 877; Neil Boister, 'The ICJ in the Belgian Arrest W arrant Case: Arresting the Development of International Criminal Law' (2002) 7 Journal of Conflict and Security Law 293; Roger O’Keefe, 'Universal Jurisdiction: Clarifying the Basic Concept' (2004) 2 Journal of International Justice 735.

64 Study, pp.xlii-xliv.

65 The Study itself notes this. See the critical remarks of Daniel Bethlehem, The Law of Armed Conflict: Problems and Prospects: Chatham House, April 18-19 2005: Transcripts and Summaries, 9, p.12.

${ }^{66}$ Report of the Secretary General Pursuant to Paragraph 2 of Security Council Resolution 808, UN Doc. S/25704, para 34.

67 Daphna Shraga and Ralph Zacklin, 'The International Criminal Tribunal for Rwanda' (1996) 7 European Journal of International Law 501, p.504.
} 
crimes provisions in the Statute, the Secretary-General noted that by including Additional Protocol II in the jurisdiction of the ICTR, the drafters of the Statute (the US and New Zealand), had gone beyond customary law. ${ }^{68}$ The Study, despite relying on the ICTR Statute, ${ }^{69}$ at no point discusses this. This is not to say that its reliance on the Statute is necessarily wrong, but it is not sufficiently explained.

Finally, in relation to the Special Court for Sierra Leone, the Secretary-General, who drafted the Statute of the Special Court (in negotiation with the Sierra Leonean government), clearly saw his mandate as limited to customary international law. As he said, again,

In recognition of the principle of legality, in particular nullum crimen sine lege, and the prohibition on retroactive criminal legislation, the international crimes enumerated, are crimes considered to have had the character of customary international law at the time of the alleged commission of the crime. ${ }^{70}$

This had specific effects. In his initial draft of the Statute, the Secretary-General included a very limited prohibition of the recruitment of child soldiers, on the basis that he was not convinced that the provision in the Rome Statute could have been considered customary in 1996. ${ }^{71}$ Interestingly, the Security Council insisted that the Secretary-General replace his suggested provision with one which conformed to that in the Rome Statute, ${ }^{72}$ 'to conform it to the statement of the law existing in 1996 and currently accepted by the international community'. ${ }^{73}$ It is very surprising that this is not mentioned by the study, particularly when it relies on the Statute of the Special Court as part of the evidence to establish that the conscription or enlistment of child soldiers has been prohibited by customary law. ${ }^{74}$

To return to what the study actually says about the statutes of international criminal tribunals, the study limits itself to the statement that it is important to stress, though it is not repeated in the commentaries, that with regard to the Statute of the International Criminal Court, there was a 'general agreement that the definitions of crimes in the ICC Statute were to reflect existing customary international law, and not create new law". ${ }^{75}$

There are a number of points that need to be made in relation to this, which implies that the Study takes a rather broad-brush approach in its reliance on the Rome Statute. The statement is one about the intentions of the drafters at Rome, it does not say that the results of the conference lived up to this hope. It must be remembered that the Rome Statute was a product of compromise. The Rome Statute itself deals with the possibility that its definitions

68 Report of the Secretary General Pursuant to Paragraph 5 of Security Council Resolution 955. UN Doc. S/1995/134, para 12.

${ }^{69}$ See, e.g. Study, pp. 10, 183, 311, 315, 320, 321, 324, 328, 334.

70 Report of the Secretary-General on the Establishment of a Special Court for Sierra Leone, 4 October 2000, UN Doc $\mathrm{S} / 2000 / 915$, para 12 .

${ }^{71}$ Ibid., paras 17-18.

72 Statute of the International Criminal Court, 2187 UNTS 3, Article 8(2)(e)(vii).

${ }^{73}$ Letter From the President of the Security Council to the Secretary-General, 22 December 2000, UN Doc. S/2000/1234, p.2.

${ }^{74}$ Study, p.596.

${ }^{75}$ Study, pp.xliv-xlv., quoting Philippe Kirsch, 'Foreword' in Knut Dörmann, Elements of War Crimes Under the Rome Statute of the International Criminal Court: Sources and Commentary (Cambridge: CUP, 2003) p.xiii. 
are not necessarily as broad as custom allows in Article 10 of the Statute. Article 10 reads '[n]othing in this Part shall be interpreted as limiting or prejudicing in any way existing or developing rules of international law for purposes other than this Statute'. The precise nature of Article 10 is a matter of considerable debate, ${ }^{76}$ nonetheless it is, if nothing else a warning that the Rome Statute is not to be taken as anything more than a base-level of what customary law is. ${ }^{77}$ Yet the commentary makes no reference to Article 10 of the Rome Statute.

Perhaps the best general comment about the normative value of the Rome Statute came from the Trial Chamber in the Furundřija case, which stated:

In many areas the Statute may be regarded as indicative of the legal views, i.e. opinio juris of a great number of States. Notwithstanding article 10 of the Statute, the purpose of which is to ensure that existing or developing law is not 'limited' or 'prejudiced' by the Statute's provisions, resort may be had cum grano salis to these provisions to help elucidate customary international law. Depending on the matter at issue, the Rome Statute may be taken to restate, reflect or clarify customary rules or crystallise them, whereas in some areas it creates new law or modifies existing law. At any event, the Rome Statute by and large may be taken as constituting an authoritative expression of the legal views of a great number of States. ${ }^{78}$

As we will see, however, some of the most controversial parts of the substantive law contained in the Rome Statute appear to be adopted by the Study, which thus contains some formulations which are more limited than custom.

The final thing to note about the treatment of the Rome Statute is the Elements of Crimes adopted under Article 9 of the Rule Statute. ${ }^{79}$ Article 9 reads: 'Elements of Crimes shall assist the Court in the interpretation and application of articles 6, 7 and 8'. The intention of the drafters of the Statute was not that these elements were to bind the Court, but to act in a persuasive fashion to guide the court. ${ }^{80}$ The Study uses the Elements on a number of occasions, but at no time does the study explain the weight which is to be attached to the Elements. Again we see that the study is wanting when it comes to explaining the precise normative status of the documents it relies on.

Moving on to judicial decisions, the Study is quite explicit that it has sympathy for the decisions of the international criminal tribunals, saying that:

\footnotetext{
${ }^{76}$ See, e.g. Leila Nadya Sadat, 'Custom, Codification and Some Thoughts About the Relationship Between the Two: Article 10 of the ICC Statute' (2000) 49 De Paul Law Review 909; contra, e.g. Kenneth S. Gallant, 'Jurisdiction to Adjudicate and Jurisdiction to Prescribe in International Criminal Courts' (2003) 48 Villanova Law Review 763.

77 See Robert Cryer, Prosecuting International Crimes: Selectivity and the International Criminal Law Regime (Cambridge: CUP, 2005) Chapters 5-6.

78 Prosecutor v Furundžija, Judgement, IT-95-17/1-T, 10 December 1998, para 227. Prosecutor v Tadić, Judgment, 15 July 1999, IT-94-1-A, para 223, but see Separate Opinion of Judge Shahabuddeen, para 3.

$79 \mathrm{ICC} / \mathrm{ASP} / 1 / 3$.

${ }^{80}$ See, Erkin Gadirov, 'Article 9' in Otto Triffterer (ed.), Commentary on the Rome Statute of the International Criminal Court (Baden-Baden: Nomos, 1999) 289.
} 
Although decisions of international courts are subsidiary sources of international law, they do not constitute State practice. This is because, unlike national courts, international courts are not State organs. Their decisions have, nevertheless, been included because a finding by an international court that a rule of customary international law exists constitutes persuasive evidence to that effect. In addition, because of the precedential value of their decisions international courts can also contribute to the emergence of a rule of customary international law by influencing the subsequent practice of States and international organisations. ${ }^{81}$

What is interesting, and perhaps concerning, about this is its omnibus nature, the jurisprudence of international tribunals is apparently considered, per se, 'persuasive evidence' of a customary rule without any reference to the quality of decisions by those Tribunals. ${ }^{82} \mathrm{It}$ is no secret that the quality of decisions between certain international criminal tribunals varies, ${ }^{83}$ as indeed it does within those tribunals. The persuasive nature of an international decision does, and ought to, depend upon its quality. Given the controversy over customary law, the evidence used for it ought to be high quality, and care must be taken not to take court decisions simply as correct restatements of custom. The Study is correct to treat the Nuremberg IMT's decision that the Hague Regulations attached to Hague Convention IV of $1907^{84}$ were customary as (now) uncontroversial. ${ }^{85}$ It does also note, on the other hand, citing Nuremberg as an example, that '[i]t appears that international courts and tribunals on occasion conclude that a rule of customary international law exists when that rule is a desirable one for international peace and security or for the protection of the human person provided there is no important contrary opinio juris. ${ }^{86}$ This appears to accept that tribunal decisions are not always defensible on traditional grounds. This, however, might be referable to what is implied by the latter part of the quote above, that after a time, many controversial determinations of customary international law by tribunals become normalised.

The influence of decisions on the study, however, is not entirely consistent. Responding to the criticism that the study does not deal with definitions of armed conflict and internationalisation of non-international conflicts, ${ }^{87}$ one of the report's authors wrote to the critics explaining

\footnotetext{
81 Study, p.xxxiv.

82 For other problems with the way in which the Study approaches case law, in relation to human rights bodies see Heike Krieger, 'A Conflict of Norms: The Relationship Between Humanitarian Law and Human Rights Law in the ICRC Customary Study' (2006) 11 Journal of Conflict and Security Law ??, ??

83 The Special Court for Sierra Leone, for example, has come under considerable criticism for the quality of the reasoning in some of its decisions, see, e.g. Deen-Racsmány, 'Taylor', supra n.18; Sarah Williams, 'Amnesties in International Law; The Experience of the Special Court for Sierra Leone' (2005) 5 Human Rights Law Review 271, p.307; Robert Cryer, 'Commentary' in Goran Sluiter and Andre Klip (eds.), Annotated Leading Cases of the International Criminal Tribunals: Volume IX (Antwerp: Intersentia, forthcoming 2006).

84 'Nuremberg IMT, Judgment and Sentence' (1947) 41 American Journal of International Law 172 p.248

85 Study, p.xliv. The ICJ, for example, has taken this view without criticism, see Legal Consequences of the Construction of a Wall in the Occupied Palestinian Territory (2004) ICJ Rep. 172, para 89; Case Concerning Armed Activities On the Territory of the Congo ICJ General List 116, para 217.

86 Study, p.xliii.

${ }^{87}$ Maclaren and Schwendimann, 'Exercise', supra n.12, pp.1226-8.
} 
All that we could have done was to repeat the various provisions in treaty law.... and possibly some dicta from case law of the ICTY. But we felt that this was not sufficiently exhaustive to make any statement. ${ }^{88}$

This is a surprising statement, given that there is a rich jurisprudence from the ICTY on internationalisation of armed conflicts, ${ }^{89}$ including at appellate level. ${ }^{90}$ The matter cannot be considered to have only been tangentially raised in the ICTY. Even if it is the case that there is a strict ratio/obiter distinction in international law, ${ }^{91}$ the issue of the applicability of the grave breaches of the Geneva Conventions, i.e. the nature of the armed conflict, was not an obiter issue. It was central to the conviction of, for example, Dusko Tadić on counts concerning Grave Breaches of the Geneva Conventions. It might also be noted that at least some of the ICTY's jurisprudence on this matter has had a considerable impact on international law. The definition of non-international armed conflict given in the Tadic interlocutory appeal was taken up almost verbatim in the Rome Statute. ${ }^{92}$

The disavowal of placing reliance on dicta from the Tribunals is also inconsistent with the treatment of such statements elsewhere in the Study. For example, the Study takes a very broad view of the customary law applicable to prohibited weapons in non-international armed conflicts. ${ }^{93}$ It is likely that their bold approach here was partially underpinned by the statement of the ICTY Appeals Chamber in the Tadic interlocutory appeal that

Elementary considerations of humanity and common sense make it preposterous that the use by States of weapons prohibited in armed conflicts between themselves be allowed when States try to put down rebellion by their own nationals on their own territory. What is inhumane, and consequently proscribed, in international wars cannot but be inadmissible in civil strife. ${ }^{94}$

The Study cites the paragraph (although not making clear how much weight it is expected to bear). ${ }^{95}$ Yet Tadić was not accused of any weapons offences, thus the statement was unquestionably obiter. Indeed, so were a considerable proportion of the decision's determinations of what customary law applied in non-international armed conflict, which are also relied on in the Study. ${ }^{96}$

These comments on the general approach complete, it is worthwhile investigating some specific areas where the Study uses the statutes and practice of the international criminal tribunals. It ought to be noted though that although elements of the Study are subject to

\footnotetext{
88 ibid., p.1227.

89 On which see Christine Byron, 'Armed Conflicts: International or Non-International?' (2001) 6 Journal of Conflict and Security Law 63.

90 Tadic, supra n.53, paras 83-162; Kordic and Cerkez.Judgment, IT-95/2-A, 17 December 2004, paras 295-378.

91 A distinction which Lauterpacht, for example, doubted, Development, supra n.3, p.61, See also Shabtai Rosenne, The Perplexities of Modern International Law (The Hague: Martinus Nijhoff, 2004) p.45. Equally, the ICTY considers there to be such concepts, Prosecutor v Aleksovski, Judgment,. IT-95-14/1-A, 24 March 2000, paras $110,113$.

92 See Prosecutor v Tadić, supra n.2, para 70; Rome Statute, Article 8(2)(e).

93 See David Turns, 'Weapons in the Customary Study' (2006) 11 Journal of Conflict and Security Law ??, pp.??

${ }_{94}$ Tadić, supra n.2, para 119.

95 Study, p.240.

96 See, e.g. Study, pp.7-8, 129, 262.
} 
criticism, the majority of the considerable use made by the study of the tribunals is not problematic. Few, if any could criticise the reference to the Nuremberg IMT Charter, for example, for the proposition that murder is a war crime. ${ }^{97}$ The majority (but not all by any means) of the uses of the Rome Statute are similarly uncontroversial. The examples chosen, however, represent some more general difficulties with the approach in the Study.

\section{TAKING THE CaSes too Seriously? The LaW OF Reprisals}

At times the study is perhaps a little over-sanguine in relation to case-law, taking some decisions as having a greater authority than their reasoning merits. Jurisprudence ought not to be adopted uncritically. ${ }^{98}$ As mentioned above, the persuasive value of case-law is directly related to its quality or reasoning. In the, admittedly controversial, case of reprisals, in particular, reprisals targeting the civilian population outside of occupied territory which are prohibited under Article 51(6) of Additional Protocol I, the study relies on a piece of obiter in one of the most controversial decisions of the ICTY, Prosecutor v Kupreškic. ${ }^{99}$ In relation to rule 146, which entirely accurately states 'Belligerent reprisals against persons protected by the Geneva Conventions are prohibited' ${ }^{100}$ the commentary concludes that

Because of existing contrary practice, albeit very limited, it is difficult to conclude that there has yet crystallised a customary rule specifically prohibiting reprisals against civilians during the conduct of hostilities. Nevertheless, it is also difficult to assert that a right to resort to such reprisals continues to exist on the strength of the practice of only a limited number of States, some of which is ambiguous. Hence, there appears, at a minimum, to exist a trend in favour of prohibiting such reprisals. The International Criminal Tribunal for the former Yugoslavia, in its review of the Martic case in 1996 and in its judgement in the Kupreškic case in 2000, found that there was such a prohibition already in existence, based largely in the imperatives of humanity or public conscience. These are important indications, consistent with a substantial body of practice now condemning or outlawing such reprisals. ${ }^{101}$

It is not the purpose of this section to deny the moral and practical problems, which are fairly well described by the Study, ${ }^{102}$ which accompany reprisals. However, the reliance on the Martic and Kupreskeic cases, although careful (the study does not assert the cases settled the issue), fails to note that the reasoning in the cases has been subjected, on a legal level, to

\footnotetext{
97 Study, p.311.

${ }_{98}$ Meron characterises the approach of the ICTY as 'conservative' on customary law, (Meron, 'Revival' supra n. 11, pp.821-829, but does not refer to a number of the more controversial cases.

99 Prosecutor v Kupreškic et al, Judgment, IT-95-16-T, 14 January 2000, paras 521-536

100 Assuming that the reference to the Geneva Conventions is to those of August 1949 rather than Additional Protocol I, as we will see.

101 Study, p.523.

102 Study pp.512-3. Although see the apposite comments in Dieter Fleck, 'International Accountability for Violations of the Jus in Bello: The Impact of the ICRC Study on Customary International Law' (2006) 11 Journal of Conflict and Security Law ??, pp.??
} 
quite devastating critique. ${ }^{103}$ As Christopher Greenwood put it ' $t$ the Trial Chamber in Kupreškić...cited virtually no State practice at all and what it did cite does not support the conclusions it drew'. ${ }^{104}$ Frits Kalshoven goes further, and states that the attempt to read practice the way the Trial Chamber did in Kupreškic, and use the Martens Clause to paper over the cracks in practice is 'founded on quicksand'. ${ }^{105}$ On that basis, he concluded that 'the Kupreškic judgment fall[s] in the category of judicial decisions that not merely have no binding force of precedent, but lack persuasive authority. ${ }^{106}$

Against this background, it is difficult to see those cases as contributing a 'trend'. The response of academics to the decision at least partially undermines the case's contribution to it. It might be noted, although owing to the timing of its publication meant that the Study could not take it into account, the UK Manual of Military Law is clear that the UK has taken the view that the decision in Kupreskic is, insofar as it relates to a customary prohibition on reprisals, simply wrong. ${ }^{107}$ Failing to refer to the commentaries on the decisions, which directly impugned the reasoning and presaged, if not influenced, State responses, is unfortunate. It is quite possible that the Study did in fact take into account these critiques. After all, it is careful not to follow the Kupreskic decision slavishly (and that point should be reiterated, as it implies that the Study has not, in practice, always taken the general view the introduction suggests). If it did take those academic views into account, however, the Study ought to have made this clear. The second volume of Study contains a plethora of practice relied upon (and excerpts from cases), to show how the rules were justified. If other considerations, such as academic commentaries, were taken into account, then it is important to state this alongside the practice. ${ }^{108}$

103 The reasoning in the case is effectively skewered by Christopher J. Greenwood, 'Belligerent Reprisals in the Jurisprudence of the International Criminal Tribunal for the Former Yugoslavia' in Horst Fischer, Claus Kreß and Sascha Rolf Lüder (eds.), International and National Prosecution of Crimes Under International Law: Current Developments (Berlin, Springer, 2001) 539. See also Frits Kalshoven, 'Reprisals and the Protection of Civilians: Two Recent Decisions of the Yugoslavia Tribunal' in Vohrah et al (eds.), Man's Inbumanity to Man: Essays in Honour of Antonio Cassese (The Hague, Kluwer, 2003) 481.

104 Ibid., p. 550.

105 Kalshoven, supra n.102, p.504.

106 Ibid., p.508.

107 Prosecutor v Kupreškic, supra n.98, paras 521-536. See Ministry of Defence, Manual of the Law of Armed Conflict (Oxford: OUP, 2004) p.421.

108 There are a number of references to academic works in the Study when it deals with the particular rules, but the vast majority of the references are simply to factual assertions. There are some references to the ICRC commentaries on the Geneva Conventions and Additional Protocols, see, e.g. Study, vol. II, pp.330, 342, 506, 545, 977, 989, 990, 1205, 1338, 1354, 1388, 1414, 1437, 1457, 1551, 1786, 1793, 2060, 2137, 214724562467 , 2487, 2512, 2880, 2895, 3195, 3286, 3299, 3528, 3591, 3883. The most heavily used piece of academic literature, which is used to assist in the determination of custom is a piece by Michael Matheson, Michael J. Matheson, 'The United States Position on the Relation of Customary Law to the 1977 Protocols Additional to the Geneva Conventions of 1949' (1986) 2 American University Journal of International Law and Politics 419. The piece is referred to e.g in the Study Vol II at pp.73, 187, 318, 351, 472, 526, 572, 664, 698, 709, 721, 834, 835, 895, 926, 988, 1134 (both). 1268, 1326, 1337, 1353, 1387, 1539, 1993, 2006, 2035, 2187, 2204, 2278, 2387, 2408, 2509, 2532, 2544, 2560, 2579, 2587, 2638, 2661, 2686, 2712, 2720, 2730, 2747, 2770, 2831, 3085, 3104, 3204,), 3382, 3392, 3420, 3451, 3469, 3478, 3487, 3498, 3993, 4077. It seems that this was (quite sensibly, given the title, Matheson's position as Deputy Legal Adviser to the US State Department and the absence of any caveat in the piece that he is speaking in a personal capacity), basically taken as a statement of US official views, rather than a judgment on its intrinsic academic merit. In a slightly ironic twist, one of the very few areas where academic commentaries are used in the Study is on the general conditions of lawful reprisals (Study Vol II, pp. 3328, 3336, 3337, 3346, 3374, 3505-3506) where earlier works by Greenwood (Christopher Greenwood, 'The 


\section{TAKing Rome too Seriously-Superior Orders, Collateral Damage AND COMMAND RESPONSIBILITY}

The Study appears to take the sometimes controversial parts of the Rome Statute at face value, ignoring the drafting history of those provisions, and ignoring academic commentary on those provisions and their customary or otherwise status. Three particular areas spring to mind on this: superior orders, the formulation of the offence of launching an attack with excessive collateral damage and (civilian) superior responsibility.

\section{Superior Orders}

To begin with superior orders, the Study, in rule 155, provides that 'Obeying a superior order does not relieve a subordinate of criminal responsibility if they subordinate knew or should have known that the act ordered was unlawful or should have known because the manifestly unlawful nature of the act.' It might be surprising, therefore that the explanation of the rule in the commentary begins by noting that the rule that superior orders are not a defence "was set forth' in the Charter of the Nuremberg and Tokyo IMTs, and that the principle was not rejected in the drafting of the additional protocols. ${ }^{109}$ This is entirely true, however, the Nuremberg and Tokyo IMTs Statutes did not contain any requirement that the order be manifestly unlawful. They excluded the defence completely. The statement in the Study is followed by the assertion that

the rule that superior orders are not a defence is restated in the Statutes of the International Criminal Court, of the International Criminal tribunals of the Former Yugoslavia and for Rwanda and of the Special Court for Sierra Leone and in UNTAET regulation No 2000/15 for East Timor. Conditions are spelled out in some detail in the Statute of the International Criminal Court: obedience to an order is not a defence when the person knew the order was unlawful of when the order was manifestly unlawful. ${ }^{110}$

This mixes two very different sets of provisions. All the documents mentioned, other than the Rome Statute, provide that superior orders are not a defence per se, but the commentary gives the impression that they are ad idem on superior orders. They almost are. The only treaty mentioned which supports the rule they assert, rather than the rule that superior orders are not a defence at all, is the Rome Statute.

The finding would have been more nuanced had it referred to the considerable academic commentary that supports or casts doubt on the customary nature of Article 33 of the ICC

'Twilight of the Lwa of Belligerent Reprisals' (1989) 20 Netherlands Yearbook of International Law and Kalshoven (Frits Kalshoven, Belligerent Reprisals (Leyden: Sitjhoff, 1971) are relied upon quite heavily.

109 Study, p.565

110 Study, p.566. 
Statute. ${ }^{111}$ Some of that academic commentary also deals with the case law (much of which is cited by the study), and explains it on the basis that it relates to generally applicable domestic laws rather than those specifically applicable to international crimes. ${ }^{112}$ This is not to say that the rule as formulated in the study is necessarily wrong, the Study does cite practice in support of the rule, however, it is fair to say that much of this practice (from both before and after Rome) seems to have been filtered through the lens of Article 33 of the Rome Statute, whilst other practice relating to the tribunals (including the ICTY and SCSL, which were meant to state the customary rules) has been seemingly downgraded to a secondary status. As the Study has done this, it needs to explain why the unequivocal rejection of a superior orders defence was acceptable when the ICTY, ICTR and SCSL Statutes were being drafted, but customary law now provides for a wider defence.

\section{Collateral Damage}

To move ion from defences, it is worth looking at an offence which the Study seems to take its formulation, rather uncritically, from the Rome Statute. This is the war crime of excessive collateral damage. The customary rule, at least according to the ICTY (whose decisions on this subject are fairly well reasoned) is that the provisions in Additional Protocol I are customary which, as serious violations of humanitarian law, are criminal. ${ }^{113}$ However, the Study's commentary to rule 156, expands upon the statement that 'serious violations of international humanitarian law constitute war crimes ${ }^{114}$ by averring that there is a war crime related to launching an attack that causes disproportionate damage, which is framed as follows: ${ }^{115}$

launching an attack in the knowledge that such attack will cause incidental loss of civilian life, injury to civilians or damage to civilian objects which would be clearly excessive in relation to the concrete and direct military advantage expected.'

The Study quite rightly notes that this wording is drawn from Article 8(2)(b)(iv) of the Rome Statute. It also candidly points out that the framing of the Rome Statute on this matter

\footnotetext{
111 See Paula Gaeta, 'The Defence of Superior Orders: The Statute of the International Criminal Court Versus Customary International Law' (1999) 10 European Journal of International Law 172; Antonio Cassese, International Criminal Law (Oxford: OUP, 2003) pp.231-242; Hilaire McCoubrey, 'From Nuremberg to Rome: Restoring the Defence of Superior Orders' (2001) 50 International and Comparative Law Quarterly 386; Charles Garraway, 'Superior Orders and the International Criminal Court: Justice Delivered or Justice Denied?' (1999) 336 International Review of the Red Cross 785.

112 See, Gaeta, ibid., p.183.

113 Prosecutor v Strugar, Decision of 22 November 2002, IT-01-42, para 10; Blaškic Appeal, paras 157-158; Greenwood, 'Customary', pp.123-125. That the provisions of Additional Protocol I on this matter was common ground between the parties in the Ethopia/Eritrea Claims Commission, Partial Award, Western and Eastern Fronts, Ethiopia's Claims 1 \& 3, 19 December 2005, para 18.

114 On the latter point, see below, pp.??

115 Study, p.576.
} 
is different to that of Additional Protocol I. ${ }^{116}$ Article 85(3)(c) of Additional Protocol I prohibits

[launching] an attack which may be expected to cause incidental loss of civilian life, injury to civilians, damage to civilian objects or a combination thereof, which would be excessive in relation to the concrete and direct military advantage anticipated

The study does note that the word 'overall' as an adjective for concrete and 'direct military advantage' is missing from the rule, although it is present in the Rome Statute, but avers that the meaning is the same. This is possibly the case although the position is not absolutely clear, ${ }^{117}$ and the interpretation of 'concrete and direct' is a matter of considerable controversy. ${ }^{118}$

However, by pointing to one alteration, the Study passes over a far more controversial one. This is an addition to the rule over the formulation in AP I. The word 'clearly' is added as a qualifier to 'excessive'. The commentary to the rule does not explain the addition of this term, which only appears in the Rome Statute. The addition of the word was controversial in Rome. It was unprecedented and opposed by a number of States. ${ }^{119}$ The addition of the term, which has had no effect on ICTY jurisprudence on the definition of the offence in customary international law, also has a negative impact on the rule. The term does not fulfill its ostensible purpose, which was to clarify the crime, but simply raises the threshold and introduces greater uncertainty into the law in this area. ${ }^{120}$

This is interesting, given that here we have a treaty (API), which has been declared by the Appeals Chamber of the ICTY to reflect custom on this point, being passed over in favour of the Rome Statute. Given that jurisprudence is considered persuasive by the Study, and the Rome Statute is thought a good reflection of custom, the Study needs to explain why one was chosen over another. Again, there is literature in the area that clarifies the customary statute of the Rome Statute accurately. ${ }^{121}$ Engagement, or perhaps explicit engagement, with the travaux (such that there are), case-law and academic commentary on this provision is important and would perhaps have led to a different rule being formulated. It would at least have blunted Daniel Bethlehem's critiques that the Study deviates from treaty texts without explaining why, and fails to explain the 'weight' it puts on practice, which are applicable here. ${ }^{122}$

116 Ibid,., p.577.

117 See, e.g. the formulation in the New Zealand Proposal Concerning Article 5, 2 July 1998, UN Doc A/Conf.183/C.1/L40, reprinted in United Nations Conference of Plenipotentiaries for the Establishment of the International Criminal Court: Official Records: Volume III: Reports and Other Documents, A/Conf.183/13, p.245. The ICRC considered it necessary to say at Rome that in their view the addition of 'overall' did not alter the interpretation of the crime, Study, pp.49-50.

118 See Dörmann, 'War Crimes' supra n.108, p.126.

119 See, e.g. New Zealand Proposal, supra n.117.

120 See Cryer, Prosecuting International Crimes, supra n.77, pp.277-279.

${ }^{121}$ See, e.g. the concerns reported in Leila Nadya Sadat, The International Criminal Court and the Transformation of International Law: Justice for the New Millennium (Ardsley: Transnational, 2002) p.165.

122 Bethlehem, supra n.65, p.15. 
Superior Responsibility

Having appraised one rule about a defence and one rule about an offence, let us turn to a principle of liability, namely command responsibility. Within the rule postulated by the Study, which is for the most part uncontroversial, one issue stands out. The traditional view, as (apparently) accepted in the ICTY, ICTR and SCSL statutes, ${ }^{123}$ is that the mental element for command responsibility is the same, whether the person is a civilian or a military superior. ${ }^{124}$ Rule 153 of the Study, on its face, appears to accept the point:

Commanders and other superiors are criminally responsible for war crimes committed by their subordinates if they knew, or had reason to know, that the subordinates were about to commit or were committing such crimes....

However in the commentary to rule 153 the Study, notes, that

for superiors other than military commanders, the Statute of the International Criminal Court uses the language: "consciously disregarded information which clearly indicated....This standard was used by the International Criminal Tribunal for Rwand in the Kayishema and Ruzindana case in 1999 to delineate the meaning of "had reason to know" for non-military commanders. ${ }^{125}$

The first problem with the Study on this point is that it does not explain the relationship between this statement and Rule 153. By stating the fact, but not further commenting on it, the implication is that the Study is supportive of the Rome Statute/Kayishema and Ruzindana approach, or at least happy to allow the statements to go uncontroverted. This is problematic. The Study ought to have made clear that it was only late in the Rome negotiations that the proposal to separate off civilian superiors from military superiors was made, and the chair of the negotiations was clearly uncomfortable about the customary status of the distinction. ${ }^{126}$

The Study's reference to the use of the Rome standard in 1999 for civilian command responsibility to interpret 'had reason to know' by the ICTR in Kayishema and Ruzindana ${ }^{127}$ also needs both contextualization and further comment. The first tribunal to deal with

123 The latter of which, it might be noted does not adopt the Rome Statute's express distinction between civilians and military superiors, despite coming after it.

124 There is a relevant distinction to be made between them but it is not at the level of mens rea, but at the point of determining if the relevant relationship falls under the test of the person exercising effective control and failing to exercise that control.

125 Study, p.562.

126 Per Saland 'International Criminal Law Principles' in Roy S. Lee (ed.), The International Criminal Court: The Making of the Rome Statute: Issues, Negotiations, Results (The Hague: Kluwer, 1999) 189 p.204.

127 Prosecutor v Kayishema and Ruinindana, Judgment, ICTR-95-1-T, 21 May 1999, paras 227-228. 
civilian command responsibility, the Tokyo IMT, made no distinction between the standards applied to military and civilian leaders in its judgment. ${ }^{128}$

In the Celebici Trial Chamber decision it was decided that that once the qualifications to become subject to the standard (i.e. effective control) are complete, then the mens rea standard is the same whether a person is a civilian or a servicemember. ${ }^{129}$ Later cases, such

as the Celebici Appeal Judgment, have sometimes been bashful about the relationship between customary law and the formulation of command responsibility in the Rome Statute. ${ }^{130}$ But the simple fact that these decisions post-date the Rome Statute, and the fact that the extent to which the Rome Statute was reflective of custom in this area was controversial in relation to an issue which was far less debated at Rome, ${ }^{131}$ at least ought to have merited some reference in the commentary. As should the academic writings that show that the standard in Rome was retrogressive with respect to customary law. ${ }^{132}$ Whether the Study's authors agree with these commentaries or not, the commentary as it stands may be faulted is both ambiguous in its relationship with the Rule and either selective or incomplete in relation to its appraisal of practice, case-law and doctrine.

\section{Reading the Small Print: The Rules and the Commentaries}

This leads to a final, more general critique that may be made of the Study. The rules themselves cannot be seen as self-contained. Like ILC rules such as those on State Responsibility; the rules in the Study have to be read with their commentary. And this is not in itself a problem, but as was noted above in relation to command responsibility what the rule gives, the commentary sometimes takes away. ${ }^{133}$ This is compounded by the fact that the Study does not always makes clear in the commentary where it is simply reporting practice for comprehensiveness rather than for its authority, and where it is intended to interpret, or qualify the language in the rule. To take, as another example, Rule 156 on war crimes. The rule itself reads 'Serious violations of international humanitarian law constitute

128 'Judgment', reprinted in B.V.A. Röling and C.F. Rüter, (eds.), The Tokyo Judmgent (Amsterdam: Amsterdam UP, 1977) pp.29-31. Although this was not uncontroversial, the dissenter who dealt with command responsibility, Judge Röling, did not distinguish civilians and military personnel in relation to the conditions for liability in this regard Dissenting Opinon of Judge Röling, in Röling and Rüter, (eds.), Tokyo Judgment, pp. 10621064, Röling's criticisms of the majority were related to the majority not appropriately dealing with the effective control test for civilians, not the mens rea, which. Judge Pal, in essence, did not accept command responsibility for either set of defendants, Dissenting Opinion of Judge Pal, ibid., p.966.

129 Prosecutor v Delalić, Delić, Mucić and Lanď̌o, Judgment, IT-96-21-T, 16 November 1998, paras 379-393. See also Prosecutor v Krnojelac, Judgment, IT-97-25-T, 15 March 2002, para 94.

130 Prosecutor v Delalić, Mucić, Delić \& Landžo, Judgment, IT-96-21-A, 20 February 2001, para 240.

131 Prosecutor v Hadžihasanović, Alagic and Kubura Decision on Interlocutory Appeal in Relation to Command Responsibility, IT-01-47-AR72, 16 July 2003.

132 See Greg Vetter, 'Command Responsibility of Non-Military Superiors in the International Criminal Court (ICC)’ (2000) 25 Yale Journal of International Law 89, pp.123-124 and Elies van Sliedregt, The Criminal Responsibility of Individuals for Violations of International Humanitarian Law (The Hague, T.M.C. Asser Press, 2003) pp.191-192. Although see Zhu Wenqi 'The Doctrine of Command Responsibility as Applied to Civilian Leaders: The ICTR and the Kayishema Case' in Sienho Yee and Wang Tieya (eds), International Law in the Post-Cold War World: Essays in Memory of Li Haopei (London, Routledge, 2001) 373.

133 See also Kreiger, 'Conflict of Norms'. supra n. 82, pp.?? 
war crimes', which seems both clear and simple, and to take the correct position on the question of whether or not a separate rule criminalising the violation (serious or not) is required. ${ }^{134}$ However, in the commentary to the rule, the Study refers to consistent ICTY and ICTR jurisprudence, traceable basically to the Tadic appeal decision, to the effect that there must be a separate rule criminalising the violation for such a violation to amount to a war crime. ${ }^{135}$ Leaving aside the fact, as the Study quite rightly notes, that earlier practice was not to this effect, ${ }^{136}$ the study seems to have sympathy for the Tadic approach, by stating that Tadic et al do 'not exclude the possibility that a State may define under its national law other violations of international humanitarian law as war crimes. The consequences of so doing, however, remain internal and there is no internationalisation of the obligation to repress those crimes and no universal jurisdiction'. ${ }^{137}$ However, if this is the case, the commentary has undermined the rule. Here we can see an over-reliance on ICTY jurisprudence without sufficient evaluation of the quality of the decisions being relied upon, ${ }^{138}$ but this time with the superaddition of greater uncertainty as even to what the rule asserted to be customary is.

\section{CONCLUSION}

The foregoing is critical of the Study. Nonetheless, it is important to note that the critique is of aspects of how the Study, in limited cases, has relied (or not relied) on documents and cases without always taking into account their background or quality. A majority of its conclusions can be supported wholeheartedly. The critiques above are emphatically not that the Study consistently overstates custom, or even that it has a tendency to. Indeed, the majority of the above is implicitly based on the feeling that in relation to at least a small number of issues, it could have gone a little further without going beyond existing law.

The work of a critic is an easy one, especially when compared to that of an author. As a work of scholarship, the Study is a stunning piece of work. Against the background of the difficulty of establishing custom at all, the Study has gone a huge way towards setting out the position under custom, and by even setting down the rules, has provided both impetus for further study in the area and a basis for debate. ${ }^{139}$ The simple fact that within the confines of

134 On which see Peter Rowe, 'War Crimes' in McGoldrick, Rowe and (eds), The Permanent International Criminal Court: Legal and Policy Issues (Oxford: Hart, 2004) 203, pp.204-205; contra, Georges Abi-Saab, 'The Concept of War Crimes' in Sienho Yee and Wang Tieya, International Law in the Post-Cold World: Essays in Honour of Haopei Li, (London, Routledge, 2001) 99, pp.112-113.

135 Study, p.571. To which might be added Prosecutor v Norman, Decision on Preliminary Motion Based on Lack of Jurisdiction, (Child Recruitment), SCSL-2004-14-AR72, 31 May 2004.

136 Study, p.571.

137 Ibid.

${ }^{138}$ For critique of the ICTY here see Robert Cryer, 'Prosecutor v Galic and the War Crime of Terror Bombing' (2004) 2 Israel Defence Forces Law Review ??, pp.?? For critique of the SCSL, see Matthew Happold, 'International Humanitarian Law, War Criminality and Child Recruitment: The Special Court for Sierra Leone's Decision in Prosecutor v. Samuel Hinga Norman' (2005) 18 Leiden Journal of International Law 283.

139 Although, as Philip Allotts point out, such debates risk forgetting that regulating war through law is an ersatz, response to the devastation that war inevitably begets, Philip Allott, 'Law and War: A Sinister Partnership' (2005) 99 Proceedings of the American Society of International Law 203. 
one piece, or even a symposium, it is impossible to do more than begin to discuss the issues raised by the Study, its approach and conclusions is testament to its extraordinary breadth, depth and vision. 